
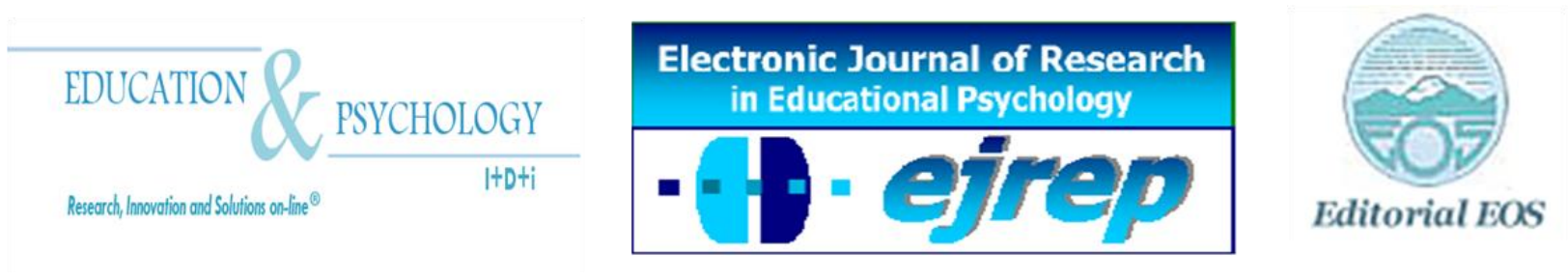

\title{
The nature of creativity: cognitive and confluence perspectives
}

\section{Olga Megalakaki ${ }^{1}$, Anna Craft ${ }^{2}$, Teresa Cremin ${ }^{3}$}

\section{France / England}

Correspondence: Olga Megalakaki University of Picardie, Team CRP-CPO EA 7273, Chemin du Thil, 80025 Amiens Cedex 1, France. E-mail: olga.megalakaki@u-picardie.fr

(C) Education \& Psychology I+D+i and Editorial EOS (Spain) 


\begin{abstract}
In the present psychology-informed literature review we address some aspects of the nature of creativity from cognitive and confluence perspectives. The authors begin by discussing models of creativity offered by cognitive and confluence approaches, focusing on the transition from univariate to multivariate models. The article explores what these literatures suggest about factors that can influence creativity, including cognitive conative and environmental ones. The article goes on to present the overlaps and distinctiveness between creativity and innovation and the vexed question of the evaluation of creativity exploring two contrasting stances of psychometric and componential approaches. The review concludes by acknowledging the complexity of the phenomenon of creativity explored here mainly through cognitive and confluence lenses touching on psychometric and social-personality approaches, and recognizes the potential of other lenses in psychology such as psychodynamic, humanistic and evolutionary, for understanding creativity.
\end{abstract}

Keywords: creativity, cognitive, confluence, complexity.

Received: 10/15/12 Initial acceptance: 10/20/12 Final acceptance: 11/14/12 


\section{La naturaleza de la creatividad: perspectivas cognitivas y confluencia}

\section{Resumen}

En la presente revisión de la literatura acerca de la psicología informativa abordamos algunos aspectos de la naturaleza de la creatividad desde perspectivas cognitivas y de confluencia. Los autores comienzan hablando de modelos de creatividad obtenidos por enfoques cognitivos y de confluencia, centrándose en la transición de modelos univariados a multivariados. El artículo explora en la literatura que se sugiere acerca de los factores que pueden influir en la creatividad, incluyendo la cognitiva conativa y la relacionada al medio ambiente. Luego presentamos las similitudes y diferencias entre la creatividad y la innovación, y la controvertida cuestión acerca de la evaluación de la creatividad, explorando dos posturas contrapuestas; los enfoques psicométricos y componenciales. Esta revisión concluye reconociendo la complejidad del fenómeno de la creatividad explorado aquí principalmente a través de una mirada cognitiva y de confluencia, tocando los enfoques psicométricos y sociales de la personalidad, y reconoce el potencial de otras miradas de la psicología, como la psicodinámica, la humanistica y la evolucionaria, para entender la creatividad.

Palabras Clave: creatividad, cognitivas, confluencia, complejidad. 


\section{Introduction}

The complex phenomenon of creativity has been defined as "the ability to produce work that is both novel (i.e., original, unexpected) and appropriate (i.e., useful, adaptive concerning task constraints)" (Sternberg \& Lubart, 1999, p. 3). Whilst there are many definitions of the phenomenon, these elements are widely accepted. The notion of creativity as generating original and appropriate outcomes comprises the four P's of Person, Process, Product, Press which Rhodes (1961) originally identified, combining the production of original and valuable outcomes with the impact of these on others. The creative process has led to a lot of work and many models have been developed. Over time, models of creativity have been enriched with many new features that came into play. In cognitive psychology it is accepted that creativity is a human quality that depends on the individual capabilities, expertise and motivation (Amabile, 1997).

\section{Models of creativity: passage of univariate to multivariate ones}

Within psychology many paradigms co-exist for understanding creativity and over time there has been a transition from more linear approaches toward more integrative, where several elements are taken into account simultaneously. Sternberg (2003a) outlines this journey through nine paradigms (mystical, psychodynamic, humanistic, cognitive, psychometric, pragmatic, social-personality, evolutionary and confluence though it could be argued that the latter two emerge from combinations of the other traditions). In the present literature review ${ }^{1}$ we focus more on the cognitive and confluence approaches to creativity, also drawing on some psychometric and social-personality perspectives.

Among the earliest published cognitive psychological models of the creative process, is that of Wallas (1926), who outlined four main stages (preparation, incubation, illumination and verification). The preparation phase is the gathering of internal information proper to each individual, and the external one coming from the environment. The incubation step is defined as the implementation of unconscious associations. During the illumination, the ideas rise to consciousness. The last stage of verification compares the ideas to reality and makes 
selections. Similarly, Guilford (1950) proposed a four-stage model, which involves the same steps than Wallas yet other more recent approaches, for example Cropley and Cropley (2008), have recognized the importance of communicating creative ideas successfully and so offer an extended model involving seven parts (preparation, activation, cogitation, illumination, verification, communication and validation $)^{2}$. However, these models cannot explain certain abilities and cognitive processes involved in creativity.

Other early cognitive models include Mednick's (1962) recognition of the role of the associative process in creativity, and Hudson's (1968) recognition that creativity involves both divergent and convergent thought. From these emerged recognition of certain abilities and cognitive processes involved in creativity, as, "a capacity to produce many ideas (fluency), an ability to change one's mental set (flexibility), an ability to reorganize, an ability to deal with complexity, and an ability to evaluate" (summarised in Lubart, 2000-2001, p.295, drawing on work by Guilford and also Torrance). More recent cognitive approaches also include studies which seek to understand computer simulations of creative thought (for example Boden, 1999, 2004) as well as the relationship between generative and exploratory phases in creativity such as the Geneplore model (Finke et al., 1992 ; Ward et al., 1999).

Thus gradually a multivariate approach fell into place, where creativity is seen as a combination of several interacting factors such as the intellectual capacity of the individual, the personality and environmental issues. In this context several models have emerged, taking into account a number of factors. Some authors described the creative process as a dynamic blend of processes that co-occur, in a recursive way throughout the work (Eindhoven \& Vinacke, 1952, in Lubart 2001) or as an integrated approach (Ghiselin (1952/1985 in Lubart 2001). Calwelti, Rappaport, and Wood (1992) suggest the simultaneity of processes such as centering on a topic, working on new ideas, expanding ideas, evaluating, and taking distance from one's work.

As the research comunity increasingly recognised the convergence of multiple components in enabling creativity, a new framing of creativity beyond cognitive models emerged, in a confluence approach. Such theorists include Amabile (e.g. 1983, 1997) exploring the rela-

\footnotetext{
2 There are some potential parallels between these stage-models of creativity and its communication, and Bisbee's ' $5 \mathrm{E}$ ' model (discussed in Bisbee et al, 2006) which has influenced science education internationally: this too consists of stages comprising Engagement, Exploration, Explanation, Elaboration and Evaluation. However it could be argued the 5E model is more focused on scientific exploration than on creativity.
} 
tionships between intrinsic motivation, domain knowledge and creativity skills. Amabile (1996) proposed a componential model of creativity comprising three components, namely, motivation, abilities in a field and processes. This model includes several phases which do not necessarily occur in a fixed sequence: (a) problem or task identification, (b) preparation (gathering and reactivating relevant information and resources), (c) response generation (seeking and producing potential responses), (d) response validation and communication (testing the possible response against criteria), and a final phase of decision making about further work.

Csikszentmihalyi $(1988,1996)$ proposed the 'systems approach' where the individual interacts with a domain of knowledge and a field (persons who value). Gardner (1983) suggested from his studies of high creators that anomalies in systems seem to generate creativity. Gruber (1989) developed an 'evolving systems model' which integrated knowledge, purpose and affect, and explored the importance of 'networks of enterprise' that support highly creative people. Sternberg and Lubart (1993), in their model, identified six different resources that may play a role in a creative production, namely, aspects of intelligence, knowledge, cognitive styles, personality, motivation and environment. More recently Lubart et al. (2003) refined this model by including emotional factors. These theories appear to explain paradigm-shifting, or 'big c' creativity where multiple components need to co-occur. Calwelti, Rappaport and Wood (1992) suggest the simultaneity of processes such as centring on a topic, working on new ideas, expanding ideas, evaluating, and taking distance from one's work.

Thus the evolution of the creative process models has progressed towards an integrated approach where complexity is recognized and cognitive, conative and environmental factors are recognised as contributing to the establishment and development of creativity (Amabile, 1983; Lubart, 1994; Sternberg \& Lubart, 1995). According to this point of view, Mumford et al. (1994) argue that creative problem solutions require expertise, adaptability, motivational and dispositional characteristics. Moreover as Lubart (2000-2001) note, the difference between creative and noncreative process focuses on a continuum rather than a dichotomy. In fact what is important for creative work is knowledge, motivation and the nature of the problem-solving task. 


\section{Factors that can influence creativity}

Current models of creativity, within the cognitive and confluence traditions, presented above, consider that many factors can influence the creativity of individuals. In addition, the combination of these factors may give different results depending on, both, the individual and the field of activity. Among these are cognitive, conative, and environmental factors (Amabile, 1983; Lubart, 1994; Sternberg \& Lubart, 1995).

\section{Cognitive factors of creativity}

In general, cognitive factors can influence creativity and are highlighted in different ways in the literature. Some years ago, Guilford (1950) noted that creativity involved certain abilities as sensitivity to problems, a capacity to produce many ideas (fluency), an ability to change (flexibility), an ability to reorganize, to deal with complexity, and an ability to evaluate. Fluency and flexibility later became a part of the Torrance tests in creative thinking (e.g. 1968). More recently, studies have explored the nature of the sub-processes involved in creativity (Lubart, 1994a; Sternberg, 1999; Sternberg \& Lubart, 1995). Between these sub-processes have been identified: problem finding, problem formulation, and problem redefinition (Mumford, Baughman, Threlfall, Supinski \& Costanza, 1996), the divergent thinking (the process of generating many alternative ideas), the process of forming idea combinations through random or chance-based processes (Simonton, 1988), the process of reorganizing information (Baughman \& Mumford, 1995; Sternberg \& Davidson, 1995), perception and information encoding (Mumford, Baughman, Supinski \& Maher, 1996), and using heuristics (Langley, Simon, Bradshaw \& Zytkow, 1987).

Mumford and their colleagues (Mumford et al., 1994) examine cognitive capacities that contribute to creative problem solving. They proposed a creative process model that organizes the sub-processes involved in categorical structures (Mumford, Mobley, Uhlman, ReiterPalmon \& Doares, 1991). Studies support the idea that the combination and reorganization of extant knowledge is used to generate new ideas or novel problem solutions, as demonstrated in the historic study of scientific revolutions (Kuhn, 1970), but do not tell us how people go about combining and reorganizing existing concepts. However, a study by Mobley, Doares and Mumford (1992), provides some clues about the nature of the combination and reorganization process. They argue that knowledge structures reflect a categorical organization of facts and principles (Barsalou, 1983; Fleishman \& Mumford, 1989; Owen \& Sweller, 1985). 
In the framework of cognitive psychology, studies of creativity refer to problem solving by analogy, which is considered as a strategy to bring together two items and to emerge a third through cognitive processing. This may be particularly relevant in science education where it might be argued that analogy is needed to transfer thinking from one area of learning to another (Gentner, 1983).

\section{Conative aspects of creativity}

Conative aspects of creativity encompass personality, motivation and emotions. Among the personality traits important for creativity, research points out perseverance, risk taking, openness to new experiences, individuality and tolerance for ambiguity (Lubart, Georgsdottir \& Besançon, 2009). For example, McCrae (1987), showed that the trait 'openness' interacts with the process of divergent thinking in order to make creative production possible. Other authors show that extraversion (Wolfradt \& Pretz, 2001) and psychoticism (Eysenck, 1993) are positively and strongly associated with creativity. Amabile's work theorised that extrinsic motivation is insufficient for creativity (Amabile, 1983, 1998, 1996) whereas interest in the activity itself is much more likely to facilitate it. Rewards, according to Amabile, actually have a destructive effect on creativity in general, particularly, on higher-order problem-solving. Amabile argues that the more complex the activity the more likely extrinsic motivation will block creativity, for if students perceive their learning as simply something they have to get through in order to 'win the prize', this reduces their capacity to be creative. This is particularly relevant given the wider performative culture in which children learn across the world. Moneta and Sui (2001), in their exploration of the lack of creativity in the highly-extrinsically motivated education system in Hong Kong, confirm this.

Besides certain personality traits, motivation also plays an important role in creativity. Studies suggest that intrinsic motivation (i.e. curiosity, etc.) contributes positively to creativity, whereas extrinsic motivation (prizes, awards, and praise from parents or teachers) sometimes is negatively related to creativity (Amabile, 1989).

More recently, studies have focused on the impact of emotional states on creative performance. However, the conclusions of these works are not consensual. The results of Isen and his colleagues (Isen, Johnson, Mertz et al. 1985; Isen, Daubman \& Nowicki, 1987) suggest that only positive emotional states, compared to neutral and negative ones, promote crea- 
tive performance. While other authors have observed that the more negative emotional states encourage creativity (Kaufmann \& Vosburg, 1997). Zenasni and Lubart (2002) suggest that contextual variables may be the cause of these differences.

Russ (1999) examined the links between creativity and emotional expressiveness in children aged 5 to 7 years old and found that the frequency of emotional themes and variety are correlated with measures of divergent thinking. In addition, emotional creativity seems to vary by gender. Averill (1999) showed that women are more creative than men, although a Polish study of almost 650 six-year-olds by Uszyńska (1998) highlighted no influence from gender, school type or location differences.

\section{Environmental factors and creativity}

These include the physical, social and cultural environment. In terms of the physical environment, one recent study suggests visible connection with natural environment, use of natural materials and less manufactured or composite surface materials, with use of visual detail and warm colours, seem to be important (Mitchell et al., 2002) whilst the values implied by the environment are highlighted by Moultrie et al., (2007). Socially, the family environment may play a role in the creative process. However the relationship of a favorable or unfavorable family environment is unclear. The role of schools and teachers is often emphasized in the development of creativity (Sternberg \& Lubart, 1993; Csikszentmihalyl, 1996). Creativity is increasingly understood to be a social phenomenon. Culturally, there is evidence of creativity being differently interpreted in the West compared with the East being seen more as about individualism in the West and the collective in the East (Kim, 2007; Ng \& Smith, 2004; Rao, 2005) yet despite this Western accounts of creativity, its place in society and how it might be fostered in educaiton, remain dominant in the research literature.

\section{Overlaps and distinctiveness between creativity and innovation}

In general, creativity can provide the basis for innovation: the result of creativity, in a market context, is innovation. Whereas, as indicated above, creativity is usually understood to be the construction of ideas or products which are new and potentially useful (Amabile, 1988), innovation is the way in which ideas are brought to a profitable conclusion, generally understood in an economic sense. The test of innovation lies in its success in the marketplace of ideas, rather than in its novelty alone. According to Cohendet and Grandadam (2008), the creative 
individual is a creator or inventor, not an innovator. Innovation itself relates not only to the novelty but also to its introduction into an existing social system (Fayolle, 2004) but is of course distinct from creativity in that the system of values relates to the profitable application of ideas.

Yet, in a study conducted by Kahl, da Fonseca \& Witte (2009), contemporary creativity research was investigated, by conducting an analysis of 119 abstracts. The study revealed that in fact the terms creativity and innovation are used interchangeably by some disciplines. Craft $(2005 ; 2008)$ has analysed the increasing link made globally between creativity and innovation, in 'marketizing' creativity critiquing this as problematic, particularly in relation to education, and arguing that harnessing education to a neoliberal narrative of need could be seen as culturally specific (a particularly Western idea) and misplaced in relation to global challenges, economic, environmental and spiritual. Sawyer (2006) by contrast argues that education increasingly needs to address the needs of society in which innovation is a core dimension. Drawing on studies of improvisation he suggests educators should connect to research about creativity and collaboration in order to develop ways of educating that attend to the role of improvisation in learning. Improvisational teams, Sawyer (2006) argues, are what are needed in the global economy and this means teaching in ways that allow students to build knowledge collectively, engage in enquiry and in productive argumentation and externalise their own developing knowledge. Sawyer identifies implications for lesson structure, curriculum design and teacher preparation.

Thus, creativity and innovation overlap in relation to their source/impetus however whereas creativity may produce results which have a variety of forms of impact, the notion of innovation implies impact in an economic context.

\section{The evaluation of creativity}

The evaluation of creativity is complex because it must take into account at the least, the individual, the task and the result of this interaction i.e. outcomes achieved. In order to assess creativity, then we must consider each component separately, but also their interactions. Thus a comprehensive assessment of the creative process must take into account the creative potential of the individual but also the creative output. In addition we must take into account the emotional and situational dimensions of personality, as we know that they played an im- 
portant role in the process of creativity (Davis 2009). Also we have to consider results from a developmental perspective, which is not unanimous on the development of creativity. For example, Torrance's (1968) results showed poor performance on the fluency and originality of children between 9 and 10 years old, while Runco and Charles (2000-2001) noted that originality and appropriateness of ideas increases with age. Finally, many authors (Han \& Marvin, 2002, Besançon, Guignard \& Lubart, 2006) recognize the existence of multiple forms of creativity. For instance they claim that "a child can have a strong creative ability in science (mathematics, science) and have difficulty in inventing a story" (Besançon et al., 2006, p. 492). In addition there is increasing recognition that creativity emerges from collaboration (John-Steiner, 2000, Chappell et al., 2008) and thus ways of 'measuring' creativity which are individually focused may be misplaced. And there is an increasing recognition of the importance of context (for example, Kim, 2006a, 2006b; Csikszentmihalyi, 1996). Creativity, such researchers argue, cannot occur in a vacuum; it is specific to particular domains and is affected, influenced and ultimately judged by the surrounding cultural context (the field).

There are a number of different ways of approaching the conceptualisation of assessment of creativity, however there appear to be three fundamental points to consider. First is what is to be assessed (i.e. is creativity seen as a process, a product, or both?); second is who should be involved in assessment (i.e. should someone outside of the creator make that judgement or does the creator have a role to play) and finally; how is creativity assessed in practice (i.e. what tools or tasks are adopted). Responses to these questions can be grouped into two kinds of approach to assessing creativity, which we now explore: psychometric and componential approaches.

\section{Psychometric approaches}

A dominant approach to the measurement of creativity has drawn on psychometrics, in other words using the same tools as for the forms of intelligence (Sternberg, 2003a). For example, in Albert \& Runco (1999) it is noted that "...creativity is a mental capacity and was an integral part of the general concept of intelligence" (p. 27). However, results of studies, about the possible links between the different aspects of intelligence (cognition, creativity and socialadaptation) according to Sternberg's model of intelligence, found heterogeneity of these aspects. In the same way, results in typically developing people show low correlations between performance on IQ tests and tests of divergent thinking (Preckel et al., 2005). 
Another series of tests widely used in the study of creativity in children is that of divergent thinking (ability to generate many solutions from a single stimulus). Among them the best known are those of Guilford (1950) and the Torrance Tests of Creative Thinking (TTCT) (Torrance, 1976). Guilford's test assesses the "intellectual structure" of individuals, based on 120 cognitive skills. The Torrance Tests are of two types, the figural test which uses three picture-based activities and devised for all levels of use from kindergarten to adulthood, which tests fluency, elaboration, originality, resistance to premature closure and abstractness of titles. The verbal test uses six word-based activities to assess fluency (number of responses produced), flexibility (number of different categories in which we can classify the answers) and originality (production of ideas relatively rare) and can be used with children from the age of six to adulthood. The tests look to evaluate participants' ability to generate many diverse ideas in response to a single stimulus, or 'divergent thinking'. In the Torrance tests, individuals are encouraged to elicit the maximum number of ideas from a verbal or pictorial stimulus. For exemple, children are asked to find the maximum of ideas from a verbal or pictorial stimulus, for instance, "name all-round the things you can think of". The TTCT (1976) is among the most used in the literature. Many recent studies have shown its metric qualities but also its theoretical and methodological limitations (Almeida et al., 2008; Kim, 2006; Lubart \& Georgsdottir, 2004; Runco, 2004). Studies on divergent thinking, (Lubart \& Georgsdottir, 2004; Mouchiroud \& Lubart, 2001) show a correlation between fluency and originality, because the large number of produced responses increases the probability to have at least an original and creative idea. However a question which arises, concerning the productions from the tasks of divergent thinking, is the appropriateness of the ideas in relation to the constraints of the task.

The concept of divergent thinking is opposed to that of convergent thinking, which reflects the ability to select the most coherent idea of several answers (a single proposal as original as possible is requested). Urban and Jellen (1996) propose a convergent/intégrative way of assessing creative potential. In this test, the TCT-DP (Test of creative thinking - drawing production), fourteen indices are considered to reflect the creativity of the person. People are asked to make a graphic production from six elements already present on a sheet (of which five are located in a frame). This type of standardized task partly simulates real creative work and involves the ability to combine several ideas, synthesize, to achieve a single production, incorporating the original constraints imposed or elements. In this type of task, many other aspects of the creative potential may be involved (cognitive, conative, and environ- 
mental) and the resulting creative products become comparable to each other. More recently Lubart et al. (2011) developed the EPOC test that measures the 'Creative Abilities of Children' in both divergent and convergent thinking. The measurements are performed currently in two areas of application, verbal and graphic. Thereafter, they will be extended to other fields (music, social and scientific are being studied).

\section{Componential approaches}

Another more qualitative frame developed for the assessment of creativity is the componential approach, this denotes the recognition of multiple 'components' or elements in creativity and attempts to assess creativity more holistically and in-context, encompassing a focus on either process or product, or, more usually, both. The work of Amabile (1983, 1990, 1996), has been influential in developing the componential approach. In assessing creativity using multiple components, Amabile has developed the Consensual Assessment Technique (CAT), which involves shared expertise around criteria derived by consensus, by judges of creativity. This field of judges may include the producer - in the case of schools, the children themselves. Judges ultimately grade creative processes and products on a five-point scale from very uncreative to very creative. There are many versions of Amabile's CAT, some formally identified as such and others reflecting aspects of it, although some, for example the Reggio Emilia pre-schools in Northern Italy (Rinaldi, 2006), use their own version of a componential approach involving artists, teachers, children and to a degree parents, in the interpretation of documentation which evidences each child's creative engagement and development. And in England the development of the Assessment of Assessing Progression in Creativity instrument, by the Center for Real World Learning and partner CCE, seeks to provide new perspectives on the assessment of creativity progression (Lucas et al, 2012) in wider European contexts.

Other approaches to componential assessment have been developed at an informal though regional level, for example in England in the regional initiative, 5x5x5=creativity (Bancroft et al, 2008). This emphasises the reach and potency of close written and photographic documentation of children's learning undertaken by adults (teachers, parents, artists and others) and reveals complexities and depth of children's creative engagement. This componential approach actively acknowledges the central role that the context in which creativity occurs has on both activity and outcomes and therefore seeks to incorporate this in its 'measurements' of creativity. This approach to the assessment of creativity, sees creativity as contextualised, rather than general. Like the previous approaches it adopts a focus on the 
product but can also be used to evaluate the process. It can be adapted for use with both individuals and pairs or groups. It sites the locus of judgement with the field of judges which may include the creator/s.

\section{Conclusion}

In conclusion, research has given much information about the process of creativity. In order to understand characteristics of highly creative people we have to examine cognitive and conative characteristics, and the wider environment also. However the study of this concept is still very complex and requires more precision in order to better understand it. As highlighted by Hauch (2002), "there is no unified theory of creativity, creativity is everywhere asked about the production and human thought, but it remains unseizable as to its nature and the motors that drive it..." (p. 15). What is perhaps most evident from this review is the diversity of lenses that may be used through which to seek insight into the phenomenon. This literature review has focused mainly on cognitive and componential approaches, drawing additionally on some psychometric and social-personality work, but other lenses such as humanistic, psychodynamic and evolutionary approaches, may be just as fruitful particularly in a world which continues to tussle between inductive and deductive approaches to knowledgebuilding.

\section{Acknowledgements}

This paper summarises part of a literature review developed as part of Creative Little Scientists, a nine-country European study (2011-2014) which is funded by European Union's Seventh Framework Programme (FP7/2007-2013) under grant agreement $n^{0} 289081$, and coordinated by Dr. Fani Stylianidou, Ellinogermaniki Agogi, Greece. Project deliverables can be found at: http://www.creative-little-scientists.eu.

Grateful thanks are due to our collaborators on this deliverable: James Clack (Open University, UK); Annette Scheersoi (Goethe University Frankfurt, Germany), Ashley Compton, Alison Riley and Jane Johnston (Bishop Grosseteste University College Lincoln, UK); Fani Stylianidou and Dimitris Rossis (Ellinogermaniki Agogi, Greece); Esme Glauert, Andrew Manches (Institute of Education, University of London, UK); Dimitris Rossis, Fani Stylianidou (Ellinogermaniki Agogi, Greece); Hilde Van Houte, Marijke De Smet, Kirsten Devlieger, (Artevelde University College, Belgium); Sari Havu-Nuutinen (University of Eastern Finland, Finland); Dan Sporea, Adelina Sporea (National Institute for Laser, Plasma and Radiation 
Physics, Romania); Manuel Filipe Costa, Paulo Varela (University of Minho, Portugal); Suzanne Gatt, Isabelle Gatt (University of Malta, Malta).

Disclaimer. This publication reflects the views only of the authors, and the Commission cannot be held responsible for any use, which may be made of the information contained therein.

\section{References}

Albert, R. \& Runco, M. (1999). A history of research on creativity. In J. Sternberg (Ed.), Handbook of creativity (pp. 16-34). Cambridge, UK: University Press.

Almeida, L.S., Prieto Prieto, L., Ferrando, M., Oliveira, E. \& Ferrándiz, C. (2008). Torrance Test of Creative Thinking : The question of its construct validity. Thinking Skills and Creativity, 3, 53-58.

Amabile. T.M. (1983). The social psychology of creativity, New York: Springer-Verlag

Amabile. T.M. (1988). A model of creativity and innovation in organization. Research in Organizational Behaviour, 10, 123-167

Amabile, T. M. (1989). Growing up creative. New York: Crown.

Amabile, T. (1997). Entrepreneurial creativity through motivational synergy, Journal of Creative Behavior, 31, 18-26.

Amabile, T.M. (1990). Within you, without you: The social psychology of creativity, and beyond. In M. A. Runco and R. S. Albert (eds.), Theories of creativity 66-91. Thousand Oaks, CA: Sage.

Amabile, T.M. (1996). Creativity Creativity in context : Update to the social psychology of creativity. Westfield Press

Amabile T.M. (1998). How to kill creativity: Keep doing what you're doing. Or, if you want to spark innovation, rethink how you motivate, reward, and assign work to people. Harvard Business Review, September-October, 77- 87.

Averill, J. R. (1999). Individual differences in emotional creativity. Structure and correlates, Journal of Personality, 67, 331-371.

Bancroft S., Fawcett, M. \& Hay, P. (2008). Researching children researching the world. Trentham Books.

Barsalou, L. W. (1983). Ad hoc categories. Memory and Cognition, 11, 211-227. 
Baughman, W. A., \& Mumford, M. D. (1995). Process-analytic models of creative capacities: Operations influencing the combination- and-reorganization process. Creativity Research Journal, 8, 37-62.

Besançon, M., J.H. Guignard \& Lubart, T.I. (2006). Haut potentiel, créativité chez l'enfant et éducation. Bulletin de Psychologie, 59, 491-504.

Boden, M.A. (1999). Computer models of creativity. In R.J. STERNBERG (ed.), Handbook of Creativity. 351-372 Cambridge: Cambridge University Press.

Boden, M.A. (2004). The creative mind: Myths and mechanisms, 2nd Ed London: Routledge.

Calwelti, S., Rappaport, A., \& Wood, B. (1992). Modeling artistic creativity: An empirical study. Journal of Creative Behavior, 26, 83-94.

Chappell, K., Craft, A., Burnard, P. \& Cremin, T (2008). Question-posing and questionresponding: the heart of 'Possibility Thinking' in the early years. Early Years, 28(3), 267286.

Cohendet, P. \& Grandadam, D. (2008). Individuals, communuties and firms in the creative process, Dime Scientific Conference, W.P. 1.1 Parallel Session on Communities and Incentives for Knowledge Creation, Mars.

Craft, A. (2005). Creativity in Schools: Tensions and dilemmas. Abingdon: RoutledgeFalmer

Craft, A., (2008). Trusteeship, wisdom and the creative future of education? UNESCO observatory, E-Journal, 1(3), Special Issue: Creativity, policy and practice discourses: productive tensions in the new millennium.

CREATIVE LITTLE SCIENTISTS (2012). Literature Review of Creativity in Education. ADDENDUM 2 of 4 of Deliverable D2.2 : Conceptual Framework. EU Project (FP7 Contract: SIS-CP-2011-289081 - Project Coordinator: F. Stylianidou (Ellinogermaniki Agogi, Greece). Lead Authors: T. Cremin, A. Craft, J. Clack (Open University, UK). Contributors: A. Scheersoi, O. Megalakaki, A. Compton, E. Glauert, A. Manches, D. Rossis, F. Stylianidou, H. Van Houte, M. De Smet, K. Devlieger, S. Havu-Nuutinen, D. Sporea, A. Sporea, M.F. Costa, P. Varella, S. Gatt, I. Gatt. Available at http:// www.creative-littlescientists.eu/sites/default/files/Addendum\%202\%20Creativity\%20in $\% 20 \mathrm{Ed} \% 20 \mathrm{FINAL} . \mathrm{pdf}$

Cropley, A. \& Cropley, D. (2008). Resolving the paradoxes of creativity: An extended phase model. Cambridge Journal of Education, 383, 355-373

Csikszentmihalyi M. (1988). The domain of creativity. In R. J. STERNBERG (ed.), The nature of creativity 325-339. New York: Cambridge University Press.

Csikszentmihalyl, M. (1996). Creativity. Nea York : HarperCollins. 
Davis, M.A. (2009). "Understanding the relationship between mood and creativity: a metaanalysis", Organizational Behavior and Human Decision Processes, 108, 25-38.

Eysenck, H. J. (1993). Creativity and personality : Suggestions for a theory. Psychological Inquiry, 4(3), 147-178.

Fayolle, A. (2004). Entrepreneuriat, apprendre à entreprendre, Paris, Dunod.

Finke, R., Ward, T., \& Smith, S., (1992). Creative cognition. Cambridge: MIT Press.

Fleishman, E. A., \& Mumford, M. D. (1989). Abilities as causes of individual differences in skill acquisition. Human Performance, 2, 225-239.

Gardner, H. (1983). Brain, mind and creativity. New York, USA: Basic Books Inc.

Gentner, D. (1983). Structure-Mapping - a theoretical framework for analogy. Cognitive Science, $7(2), 155-170$.

Gruber, H. (1989). Networks of enterprise in scientific creativity. In GHOLSON, B., SHADISH, W.R., NEIMEYER, R.A., HOUTS, A.C.C. (eds.), Psychology of science: Contributions to meta-science. 246-265 Cambridge; Cambridge University Press

Guildford, J.P. (1950). Creativity. American Psychologist, 5, 444-454.

Han, K.S. \& Marvin, C. (2002). Multiple creativeness ? Investigating domain-specificity of creativity in young children. Gifted Child Quaterly, 46, 98-109.

Hauch V. (2002). Créativité et décision stratégique : la nécessité d'une définition. Gestion 2000, 2, 15-29.

Hudson, L. (1968). Contrary imaginations. London: Pelican

Isen, A. M., Daubman, K. A., \& Nowicki, G. P. (1987). Positive affect facilitates creative problem solving. Journal of Personality and Social Psychology, 52(6), 1122-1131.

Isen, A. M., Johnson, M. M. S., Mertz, E.,\& Robinson, G. (1985). The influence of positive affect on the unusualness of word associations, Journal of Personality and Social Psychology, 48, 1413-1426.

John-Steiner, V. (2000). Creative collaboration. New York, Oxford University Press.

Kahl, C.H., da Fonseca, L.H., \& Witte, E.H. (2009). Revisiting Creativity Research: An Investigation of Contemporary Approaches. Creativity Research Journal, 21, (1), 1-5.

Kaufmann, G., \& Vosburg, S. K. (1997). "Paradoxical" mood effects on creativity problem solving.. Cognition and Emotion, 11,(2), 151-170.

Kim, K.J. (2006). Is creativity unidimensional ou multidimensional ? Analyses of theTorrance tests of creative thinking. Creative Research Journal, 18, 251-259.

Kim, K. H. (2006a). Is creativity unidimensional or multidimensional? Analyses of the Torrance Tests of Creative Thinking. Creativity Research Journal, 18(3), 251-259. 
Kim, K. H. (2006b). Can we trust creativity tests? A review of the Torrance Tests of Creative Thinking TTCT. Creativity Research Journal, 18(1), 3-14.

Kim, K. H. (2007). Exploring the interactions between Asian culture Confucianism and creativity. Journal of Creative Behaviour, 41(1), 28-53.

Kuhn, T. S. (1970). The structure of scientific revolutions. Chicago: University of Chicago Press.

Langley, P., Simon, H., Bradshaw, G. L., \& Zytkow, J. M. (1987). Scientific discovery: Computational explorations of the creative process. Cambridge, MA: MIT Press.

Lubart ,T., (2000-2001). Models of the Creative Process: Past, Present and Future. Creative Research Journal, 13, 295-308.

Lubart, T., (1994). Creativity. In R. J Sternberg (Eds.), Thinking and problem solving (pp. 289-332). New York : Academic Press.

Lubart, T., (1994a). Creativity. In R. J. Sternberg (Ed.), Thinking and problem solving (pp. 289-332). New York: Academic.

Lubart, T., Besançon, M., \& Barbot, B., (2011). EPoC : Évaluation du potentiel créatif des enfants. Editions Hogrefe France.

Lubart, T. \& Georgsdottir, A.S. (2004). Créativité, haut potentiel et talent. Psychologie française, 49, 277-291.

Lubart, T., Georgsdottir, A., \& Besançon, M. (2009). The nature of creative giftedness and talent. In T. Balchin, B. Hymer, \& D. Matthews (Eds.) The Routledge international companion to gifted education, 42-49. New York: Routledge.

Lubart, T., Mouchiroud, C., Tordjman, S. \& Zenasni, F. (2003). Psychologie de la créativité. Paris: Armand Colin.

Lucas, B., Claxton, B., \& Spencer, E. (2012). Progression in Creativity: Developing new forms of assessment. Background Paper for the OECD conference "Educating for Innovative Societies" April. Available at: http://www.oecd.org/edu/ceri/50153675.pdf

McCrae, R. R. (1987). Creativity, divergent thinking, and openness to experience. Journal of Personality and Social Psychology, 52, 1258-1265.

Mednick, S. 1962. The associative basis of the creative process. Psychological review, 69(3), 220.

Mitchell, L., McCoy, J. \& Evans, G. W. (2002). The Potential Role of the Physical Environemnt in Fostering Creativity. Creativity Research Journal, 14(3-4) 409-426 
Mobley, M. I., Doares, L. M., \& Mumford, M. D. (1992). Process analytic models of creative capacities: Evidence for the combination and reorganization process. Creativity Research Journal, 5, 125-155.

Moneta, G.B. \& Siu, C.M.Y. (2001). Intrinsic motivation, academic performance, and creativity in Hong Kong College students. Journal of College Student Development, 43(5), 664683

Mouchiroud, C. \& Lubart, T.I. (2001). Children's original thinking: an empirical examination of alternative measures derived from divergent thinking tasks. Journal of Genetic Psychology, 162, 382-401.

Moultrie, J., Nilsson, M., Dissel, M., Haner, U.-E., Janssen, S. \& van der Lugt, R. (2007). Innovation spaces: Towards a framework for understanding the role of the physical environment in innovation. Creativity and Innovation Management, 16, 53-65

Mumford, Michael D., Connelly, Mary S., Baughman, Wayne A., Marks, Michelle A., (1994). Creativity and problem solving: Cognition, adaptability, and wisdom. Roeper Review, 16, 241-246.

Mumford, M. D., Baughman,W. A., Supinski, E. P., \& Maher,M. A. (1996). Process-based measures of creative problem-solving skills: II. Information encoding. Creativity Research Journal, 9, 77-88.

Mumford, M. D., Baughman,W. A., Threlfall, K. V., Supinski, E. P., \& Costanza, D. P. (1996). Process-based measures of creative problem-solving skills: I. Problem construction. Creativity Research Journal, 9, 63-76.

Mumford, M. D., Mobley, M. I., Uhlman, C. E., Reiter-Palmon, R., \& Doares, L. M. (1991). Process analytic models of creative capacities. Creativity Research Journal, 4, 91-122.

$\mathrm{Ng}$, A. K. \& Smith, I. (2004). Why is there a paradox in promoting creativity in the Asian classroom? In L. Sing, A. Hui, \& G. Ng (eds.), Creativity: When East meets West. 87-112 Singapore: World Scientific Publishing

Owen, E., \& Sweller, J. (1985). What do students learn while solving mathematics problems? Journal of Educational Psychology, 77, 272-284.

Preckel, F., Holling, H. \& Wiese, M. (2005). Relationship of intelligence and creativity and non-gifted students : An ivestigation of treshold theory. Personality and Individual Differences.

Rao, C. (2005). Myth and the creative process: A view of creativity in the light of three Indian myths. Creativity Research Journal, 17(2-3) 221-240.

Rhodes, M. (1961). An analysis of creativity. Phi Delta Kappa, 42, 305-310. 
Rinaldi, C. (2006). In dialogue with Reggio: listening, researching and learning. Oxford: Routledge

Runco, M.A. (2004). Divergent thinking, creativity and giftedness. In : Sternberg, R.J. Definitions and conceptions of giftedness. Thousand Oaks : Corwin Press

Runco, M.A., \& Charles, R.E. (2000-2001). Developmental trends in the evaluative and divergent thinking of children, Creativity Research Journal, 13, 417-437.

Russ, S. W. (1999). Play, affect and creativity: Theory and research. In S. W. Russ (Eds.), Affect, creative experience and psychological adjustment (pp. 57-75). Philadelphia : Taylor \& Francis.

Sawyer, R.K. (2006). Educating for innovation. Thinking Skills and Creativity, 1(1) 41-48

Simonton, D. K. (1988). Age and outstanding achievement: What do we know after a century of research? Psychological Bulletin, 104, 163-180.

Sternberg, R.J (1999). Handbook of Creativity, Cambridge Press.

Sternberg, R. J. (ed.), (2003a). Wisdom, Intelligence and Creativity Synthesized. Cambridge: Cambridge University Press

Sternberg, R. J., \& Davidson, J. E. (Eds.). (1995). The nature of insight. Cambridge, MA: MIT Press.

Sternberg R.J., \& Lubart, T. (1993). Creative giftedness: A multivariante investment approach. Gifted Child Quarterly, 37 (1), 7-15.

Sternberg R.J., \& Lubart, T. (1995). Defying the crowd: cultivating creativity in a culture of conformity, New York, The Free Press.

Sternberg R.J., \& Lubart, T. (1999). The concept of creativity: Prospects and paradigms. In Sternberg, R.J. (ed.), Handbook of creativity 3-15 Cambridge, Cambridge University Press

Torrance, E.P. (1976). Test de pensée créative. Paris : Editions du Centre de Psychologie Appliquée.

Torrance, P. (1968). A longitudinal examination of the fourth grade slump in creativity, Gifted Child Quarterly, XXIX, 6A, 195-199.

Uszyňska, J. 1998. Artistic and verbal creative capacity of 6-year-old children and their psychopedagogic and social conditioning. International Journal of Early Years Education, 6(2), 133-141

Wallas G. (1926). The Art of Thought, Harcourt, Brace \& World. NY.

Ward, T. B., Smith, S. M., \& Finke, R. A. (1999). Creative cognition. In R. J. STERNBERG (ed.), Handbook of creativity 189-212. Cambridge: Cambridge University Press. 
Wolfradt, U., \& Pretz, J. E. (2001). Individual differences in creativity : Personality, story writing, and hobbies. European Journal of Personality, 15, 297-310.

Zenasni, F., \& Lubart, T. I. (2002). Effects of emotional states on creativity. Current Psychology Letters : Behaviour, Brain and Cognition, 8, 33-50. 
The nature of creativity: cognitive and confluence perspectives

[This page intentionally left blank] 